\section{Democracy Beyond the Human}

Jamie van der Klaauw

Krisis 41 (2): 127-137.

\section{Review of}

Schinkel, Willem en Rogier van Reekum. 2019

Theorie van de kraal: kapitaal-ras-fascisme. Amsterdam: Boom uitgevers.

Schinkel, Willem. 2020. De hamsteraar: kritiek van het logistiek kapitalisme. Amsterdam: Boom uitgevers.

Schinkel, Willem. 2021 Pandemocratie. Amsterdam: Editie Leesmagazijn.

\section{DOI}

10.21827/krisis.41.2.37817

\section{Keywords}

Fascism, Capitalism, Logistics, Biopolitics,

Democracy, Pandemic, Sociology

\section{Licence}

This work is licensed under a Creative Commons Attribution 4.0 License International License (CC BY 4.0). (C) 2021 The author(s). 


\section{Democracy Beyond the Human}

Jamie van der Klaauw

Willem Schinkel, als socioloog verbonden aan de Erasmus School of Social and Behavorial Sciences, is een zeer productief schrijver. De laatste jaren schrijft hij sneller dan ik kan lezen, of eigenlijk sneller dan ik zijn boeken verwerken kan. Hoofdzakelijk keert Schinkel zich tegen de bestaande laatkapitalistische (neo)liberale orde. Orde is bij uitstek een sociologisch onderwerp, en ook zijn antikapitalistische gedachtegoed is te situeren in de Marxistische/sociologische traditie, dit alles doorspekt met dekoloniale en antiracistische inzichten van denkers uit verschillende tradities. Een academicus met een activistische inborst die zich de laatste tijd meer en meer roert ook binnen die bestaande orde. Bijvoorbeeld door middel van zijn bijdragen aan politieke nieuwkomer BIJ1. Zo'n liminale positie neemt hij vaker in. Waar hij zich in Theorie van de kraal (2019) nog keert tegen het doelloze concurreren van academici die maar willen voldoen aan de publicatiedruk (het publish or perish), zo publiceert hij sindsdien zelf in moordend tempo. Schinkel wil met zijn werk vooral een knuppel in het hoenderhok gooien om ons allen zo te confronteren met de spanningen en tegenstellingen die spelen in de samenleving en die maar al te vaak bedekt worden met de mantel der geleerdheid en beschaving. Uit de vele woekeringen van het leven ontwaart Schinkel een woekering die zich opwerpt als iets ánders, als orde. Vanuit die positie claimt het andere woekeringen te kunnen beoordelen, hun plaats te wijzen. Of problematischer: te kunnen beknellen en zelfs verstikken. Maar, hoe verhoudt Schinkels theoretische keer tegen de orde zich tot zijn eigen politiek? Wat blijft er dan nog over van de democratie?

Willen we een antwoord formuleren op de bovenstaande vragen, is het eerst noodzakelijk om de theoretische basis waarop Schinkels programma steunt te expliciteren en nader te beschouwen. En waar beter te beginnen dan in het boek dat de laatste jaren het theoretische zware werk doet voor Schinkel, een coproductie met collegasocioloog Rogier van Reekum: Theorie van de kraal. In dit werk worden de begrippen woekering, als aanduiding voor het vrije leven, en kraal, de aan orde gelieerde term voor de ruimte die aan leven wordt gelaten, geïntroduceerd. Centraal staat de spanning tussen de begrippen en hoe deze tot uiting komt in hoofdzakelijk de domeinen van de politiek, economie en ecologie.Voordat Schinkel en Van Reekum dit begrippenpaar inzet in dienst van de analyse daarvan en kritiek van de huidige orde, wordt de toon in het boek meteen gezet door een zogenoemd nulde hoofdstuk. Een herkenbare toon voor wie Deleuze \& Guattari's Mille Plateaux (1980) heeft gelezen, maar een sprekende toepassing niettemin. Het nulde hoofdstuk houdt zich bezig met het onderwerp in de redekundige zin, en dan specifiek: het wij. Dat 'smerige woordje', aldus Schinkel en Van Reekum $(2019,7)$ doet hier dienst als beginpunt voor een kritiek op kantiaanse leest geschoeid met een benjaminiaanse twist. Het expliciteert en problematiseert het 'wij' dat impliciet vervlochten is in het verhaal dat wij over onszelf vertellen. Wij is namelijk geen neutraal woord, maar een politieke daad, een woord dat verdoezelt en wordt verdoezeld. Een mogelijkheidsvoorwaarde voor de politieke operatie waarlangs het geweld in de samenleving wordt verhuld en het gewelddadige van de samenleving wordt goedgepraat. Allemaal in naam van een wij dat inclusief klinkt, maar vooral dient 
als het beginpunt van een onderscheid tussen wij en zij. Een 'wij' dat hoofdzakelijk buitensluit.

Dit is naast een aantijging tegen de bestaande orde, waarin het 'democratische' wij dienstdoet als legitimering van geweld, ook een ontologische conditie. Taal is ons medium en die mediatie is onontkoombaar. Sinds de val uit het paradijs - wat Schinkel het meest uitgebreid beschrijft in zijn later gepubliceerde proefschrift Aspects of Violence - beschikken wij niet langer over de onmiddellijke toegang tot de natuur der dingen (2010, 88-90). Taal is daarmee innig verbonden met verschil, met goed en kwaad, maar ook een performatieve daad, het medium waardoor goed en kwaad gerealiseerd worden. Geweld moeten we dan ook niet strikt opvatten in de fysieke zin - dat is hoe de staat geweld definieert - , maar in verhulling, in het benoemen van en het onderscheiden tussen - klassieke operaties van zowel de sociologie als de filosofie. Hier openbaart zich de spanning in het werk van Schinkel in zijn meest abstracte vorm. Want, enerzijds zijn dit soort operaties voor de mens per definitie zondig, bij gebrek aan directe toegang tot de dingen zijn wij verdoemt tot het in het leven roepen van (re) presentaties van dingen. Anderzijds poogt Schinkel de verdoezelende gewelddadigheid van het hedendaags taalgebruik als historisch gegroeid onrecht te vatten.

Kortom, woorden doen ertoe, volgens Schinkel. Affecten van taal, van taalgebruik, staan centraal in het werk van Schinkel niet alleen vanwege de mogelijke verhullingsoperaties die ermee gepleegd kunnen worden, nee, woorden, zinnen, spreken, het zijn daden op zich. Die vervolgens hun weerklank en effecten hebben op de organisatie van het leven. De taal, als strijdtoneel, als situering van geweld, is dus niet slechts zondig. Het kan gebruikt worden om nieuwe affecten in te brengen en oude vastgeroeste connotaties weer los te weken. Dit komt naar voren in Schinkels paradoxale verhouding tot politieke correctheid. Waar Schinkel in 2007, rondom de publicatie van Sociale hypochondrie, zijn werk nog promoot met een pleidooi voor politiek incorrect denken ${ }^{\mathbf{1}}$, vóór het benoemen van de verhullingsoperaties van de (neo)liberale orde, is hij de laatste jaren juist bekend geworden om zijn pleidooi voor politieke correctheid, of eerder voor de verwerping van de tegenwerping van politieke correctheid. Deze keer moet worden gelezen als een herpositionering ten overstaan van een veranderende wereld. In de bijna vijftien jaar sinds Sociale hypochondrie heeft het politieke strijdtoneel namelijk een inversie ondergaan. Probeerde de bestaande orde in eerste instantie nog met woorden te verhullen, nu probeert ze met woorden te benoemen, de keerzijde van dezelfde operaties. Schinkels eerdere tactiek, om in naam van vrijheid en waarheid durven te benoemen, is daarmee gecoöpteerd in dienst van de bestaande orde.

Deze herpositionering werkt specifieke theoretische overwegingen op. Wat betekent dit voor de hegemoniale positie van het politiek correcte en voor de kracht van de woorden zelf? Taal op zich werkt ordenend. En politieke correctheid, evenals de aantijging ervan, zijn altijd zowel operaties van verhulling en openbaring. Wat maakt deze paradox dan (tijdelijk) ondergeschikt aan de politiek-strategische keuze één beider zijden te benadrukken? Ofwel wat maakt het één eigen, een woekering van het leven, en het ander oneigenlijk, kraal in naam van de bestaande orde? 


\section{Fascisme: mens, kapitaal, aarde}

Het antwoord op die vraag heeft een filosofisch en een politiek component. Het filosofische component betreft het onderscheid tussen de proliferatie van het leven en de beknotting ervan, tussen een bijdrage aan de verscheidenheid van levensvormen, levensvatbare vormen, en de inperking van levensvormen in naam van een specifieke levensvorm, in naam van een orde. Sterker nog, is er één rode draad door het werk van Schinkel te vinden dan is het wel dat precies orde zelf problematisch is. In Sociale hypochondrie heeft dit nog voornamelijk betrekking op de sociologie in haar poging van wat in feite een fluïde massa is een oneigenlijk geheel te maken door middel van benoemen en onderscheiden, via het gebruik van het woord maatschappij en het oordeel wie daar wel of niet deel van uitmaakt of mag uitmaken. Welk bevolkingselement heimlich is en welke dan wel via integratie dient te worden opgenomen, dan wel via uitzetting moet worden verwijderd - voor Schinkel innig verbonden met de poging politiek te bedrijven op het niveau van het maatschappelijk lichaam. Is dit in Sociale hypochondrie nog in koelbloedige analyse gesteld, wordt dit vooral vanaf Theorie van de kraal een kwestie van affect en inzet van een politieke strijd, het tweede component. Een strijd die zich afspeelt in de taal en de affecten, maar waarvan de inzet juist de weerklank van die taal en affecten in het sociale leven behelst: de materiële condities, politieke hiërarchieën en sociale systemen. Door het leven in de bestaande orde te benoemen als kraal, een omsloten ruimte voor vee, wordt onze verbeelding aangesproken om die systemen en hiërarchieën weer te expliciteren. De kraal is het gebied dat de orde aan ons toelaat. Niet langer als vrije ruimte voor het leven, door Schinkel en Van Reekum woekeringen genoemd, maar als oneigenlijke toe-eigening daarvan $(2019,11)$. Orde is een woekering die zichzelf niet meer herkent als woekering, maar als iets dat daarbovenuit komt en zich het recht toe-eigent om andere woekeringen te remmen in hun groei, te beknellen, of zelfs te verstikken. Overigens bedoelt Schinkel ons hier niets nieuws mee te vertellen, wij kennen het namelijk allemaal al onder de noemer fascisme.

Fascisme ligt binnen de theorie van de kraal ten grondslag aan de verhullingsoperaties van het (neo)liberalisme. Niet slechts het fascisme als politieke beweging, of zelfs het fascisme dat Schinkel zelf veelvuldig aanhaalt in de woorden van Benjamin: mobilisatie zonder verandering van de productieverhoudingen. Nee, eerder het fascisme dat Foucault besprak in het voorwoord van Deleuze \& Guattari's L'anti-Oedipe (1972): het fascisme dat in ons allen schuilgaat, waardoor wij verlangen naar datgene wat ons onderdrukt en exploiteert. Dit wordt over drie schijven behandeld, elk via een eigen hoofdstuk en elk symbool voor aspecten die Schinkel consistent terug laat komen in zijn werken: politiek, economie en ecologie.

Het eerste hoofdstuk in die driedeling is 'Randmensen', dat een combinatie is van een 'kritiek' op klassiek politiek denken, specifiek liberalisme en zijn wortels in het denken over de 'natuurstaat' en het sociaal contract dat ons moet leiden naar beschaving. Randmensen zijn namelijk niet mensen aan de rand van de samenleving, maar mensen die vinden dat ze zelf een rand hebben, een individueel contour. Neoliberale subjecten die randen, contouren, of scherpe grenzen waarderen en ambiëren op individueel en maatschappelijk niveau. Dit gaat langs verschillende aspecten van kolonisatie, marginalisatie, identiteit, om uit te komen op een enkele tweespalt: waar een bepaald 
liberaal-fascisme - verpersoonlijkt in de witte man - vanuit haat vertrekt en op haat uit is, zoeken Schinkel en Van Reekum zijn tegenstelling niet in vrijheid (dat is niet de tegenhanger van haat) maar in vreugde en vooral liefde. Kritiek schreef ik zojuist tussen aanhalingstekens omdat Schinkel en Van Reekum dit expliciet afwijzen. Kritiek is namelijk verankerd in een dialoog van de bestaande orde, moet zich altijd al daartegen verhouden, en dat is nu juist precies niet waar Schinkel en Van Reekum op uit zijn. Maar, als het niet kritiek is, wat is het dan nog wel? Zoals we zullen zien, geen politiek meer, maar theologie.

Het volgende hoofdstuk, schulden, verplaatst het speelveld naar de economie. Theoretisch het sterkste hoofdstuk waar ook de basis wordt gelegd voor het latere De hamsteraar (2020) en ook doorklinkt in Pandemocratie (2021). Dit hoofdstuk van Theorie van de kraal zit vol van interessante observaties en pakkende karakteriseringen daarvan. Bijvoorbeeld over de politieke aard van het economisch 'boekhouden', een langlopende lijn in Schinkels werk, van hoe de economische dimensie door de hele maatschappij gedrongen is en daarmee niet alleen mensen op waarde schat, maar tegelijk ook tot die waarde verdoemt: "[...] de schuld is zowel een indicatie van wat we waard zijn als ons verdiende loon. Bewijs en straf ineen" (Schinkel en Van Reekum 2019, 117). Dat boekhouden is dus het systeem dat bepaalt wat waar in de samenleving staat, de economie heeft, in de Europese context, de rol van de Bijbel overgenomen. Niet langer lees je de Bijbel om je plaats in de wereld te kennen, zoals het beroemde citaat van Hegel luidt, maar je bankafschrift, de balans van je rekening. Economische schuld is daarmee ook een soort 'originele zonde', aldus Schinkel, de verrekening waar het leven in dienst van gaat staan. En dit heeft een tekenende terugslag op het voorgaande hoofdstuk: migratie is een nooit te vereffenen schuld. De migrant staat namelijk in het rood bij de samenleving waar naartoe gemigreerd is, maar hoewel deze morele schuld economische aflossing vereist, kan hij nooit helemaal worden afgelost. Ten slotte is de mogelijkheidsvoorwaarde van dit alles, van het hele economische systeem, en daarmee het begrip dat het zwaarste werk verricht: schaarste. Een begrip waarop ik zal terugkomen aangezien het een sleutelbegrip is in niet alleen Theorie van de kraal, maar meer nog in De hamsteraar en ook in Pandemocratie. Schaarste is precies het type (kunstmatige) woekering dat zichzelf als (natuurlijke) orde presenteert. Schaarste is namelijk geen ontologisch feit, maar het effect van verdeling.

De derde en laatste schijf in Theorie van de kraal is 'Aarde': een hoofdstuk over de menselijke verhouding tot de (natuurlijke) wereld. Problematiseren Schinkel en Van Reekum het idee van de verloren natuurstaat nog in het eerste hoofdstuk, opent dit hoofdstuk met een theologische conceptie van de aarde als verloren natuurstaat: "Er is geen weg terug naar de aarde. Aarde is de permanente en wilde productie van verschil. Aarde is woekering, wordende aanwas van Geschiedenis. Voor zover wij woekeren, zijn wij aardlingen. En voor zover we ordenen, zijn we eenlingen" (Schinkel en Van Reekum 2019, 163). Om hier vervolgens aan toe te voegen: "Maar als eenlingen zijn we altijd al aardlingen, want in weerwil van de hallucinaties van de orde, is ordenen een modaliteit van woekeren" (ibid.). Een poging dus om de mens te ontdoen van zijn illusies, van zijn oneigenlijke vervreemding. Maar, hier botst Schinkels marxisme met het ontologisch feit van die vervreemding als immanente mogelijkheid van de 
'menselijke natuur'. Juist Schinkel doet ook aan (filosofische) vervreemding, zoals we zullen zien bij De hamsteraar. Juist ook Schinkel heeft een vorm van orde voor ogen. En juist ook woekeren is verstikken, beknellen en ruimte innemen.

Maar, voor ik daar verder op inga, nog een laatste hoofdstuk uit Theorie van de kraal.Wellicht de meest bijzondere, maar tegelijk een logische theoretische uitkomst van Schinkel en Van Reekums houding. Namelijk, een keer naar het abstracte en protestants aandoende idee van 'pure liefde'. Deze 'liefde' is puur abstract omdat het alleen in deze vorm geweldloos gemaakt kan worden. Schinkel en Van Reekum verzanden in de klassieke problematiek van theoretische schoonheid en (on)toepasbaarheid die al sinds Kant wordt besproken. Theoretisch schoon omdat, inderdaad, vuur met vuur bestrijden niet werkt, de enige manier om de vicieuze cirkel van het haat en geweld te doorbreken, is liefde en geweldloosheid. Maar, ontoepasbaar, want hoewel we het hier theoretisch over eens kunnen zijn, heeft dit praktisch geen uiting. Niet slechts omdat, zoals Schinkel en Van Reekum zelf zeggen, wij nog niet weten hoe te leven, maar ook omdat de praktijk nooit pure theorie is. De weg naar de hel is geplaveid met goede bedoelingen en een oproep tot liefde is slechts de ideologische bevestiging in naam waarvan alles altijd al wordt gedaan - ook het fascistische, ook het slechte.

\section{Logistiek kapitalisme en de hamsteraar}

Eindigt Theorie van de kraal in 2019 nog in de impasse van de abstractie, begint met het in 2020 verschenen De hamsteraar Schinkels poging om dit theoretisch raamwerk desalniettemin direct toe te passen op de hedendaagse samenleving, weer langs de schijven van politiek, economie en ecologie, ditmaal gespecifieerd naar de politieke economie in tijden van een biologisch-ecologische crisis. Centraal in dit publiekswerk staat de figuur van de hamsteraar, wat ten opzichte van de liberaal-kapitalistische orde een karikaturale uiting is van hoe de burger altijd al wordt gezien: "iemand die participeert door naar willekeur en uit vermeend eigenbelang zich op geïndividueerde manier een leven bijeen te kopen" $(2020,21)$. Schinkels punt is duidelijk, hamsteren is in de huidige context een probleem, de vraag die hij opwerpt: voor wie is het nu precies een probleem en waarom?

Hamsteren kan uiteindelijk niet beoordeeld worden langs de meetlat van solidariteit, want het consumentisme waar het hamsteren een uitwas van is, is bij uitstek "die vorm van subjectiviteit die zich op geen enkele manier nog via solidariteit vormgeeft" (ibid., 41). Schinkel betoogt dat er een hypocrisie in het verwijt van 'hamsteraar' ligt, namelijk de hamsteraar doet precies wat hem verteld is te doen: zich veilig kopen als consument. Hier verbindt Schinkel een krachtige boodschap aan:"die moraliserende kritiek op het hamsteren is precies daarom verdacht. Want het is een kritiek die gericht is op consolidatie van kapitaalaccumulatie door die subjecten tot de orde te roepen die, paradoxaal genoeg, precies doordat ze de perfectste belichaming van het kapitalistisch subject zijn, zand in de wielen van de logistieke productie- en consumptiemachine gooien" (ibid., 42). Hoewel Schinkel terecht de hamsteraar opvoert als 'vlek' op het blazoen van logistiek kapitalisme, had dit betoog sterker geweest als het expliciteerde hoe consistent het tegelijkertijd ook is. In het neoliberalisme is het morele appel altijd in dienst van de markt, die dienstbare rol verschuift dus in de tijd en de omstandigheden 
naarmate de markt dat vereist. Het kopen van Mark Rutte - "Koop die auto!" - van 2013 is niet hetzelfde als het 'leegkopen van winkels' in 2020. Juist omdat de hamsteraar niet de perfecte belichaming is van het kapitalistisch subject, juist omdat de hamsteraar de informele regels van het spel niet helemaal begrijpt, legt hij dat systeem bloot. De boodschap van Schinkel is interessant, als een soort apologie van de hamsteraar. Hoewel niet een echte apologie, want hamsteren is altijd reactionair, in dienst van het oude systeem, van de oude spelregels. Moraliseren is echter niet het devies, juist omdat de hamsteraar het eigenlijk doelwit openbaar makt: de just-in-time economie (ibid., 43). Het doel van het boek is dan ook: een bijdrage leveren aan een analyse van de mogelijkheidsvoorwaarde van het logistiek kapitalisme op grond van de manier waarop de productie en distributie van levens-middelen - in de breedste zin van het woord georganiseerd worden, in een enkel woord gevat als: biologistiek (ibid., 43; 50).

Die hamsteraar wordt in het tweede en wellicht 'grappigste' hoofdstuk in een tour de force van taalkundig-cultureel onderzoek naar de 'hamster' geduid. In een aaneenschakeling van beelden over mens en dier legt Schinkel ons haarfijn uit hoe het dierlijke als irrationeel problematisch tegenover het rationele menselijke wordt gezet. Zo ook de figuur van de hamster, die transformatieve tegenstrijdigheid kent. Hoewel de hamster al lang bekendstaat als een lieflijk huisdier, is het beeld dat in een hamsteraar nog doorechoot die van de 'korenwolf' of eerder de 'wolf', die gierigaard die uit eigen belang voorraden aanlegt en daarmee anderen het leven onmogelijk maakt. Tegenstrijdig echter is de tijdloosheid waarmee deze beelden worden verbonden. Als dit universele operaties zijn, wat helpt het dan nog om de onderliggende instituties in dienst van kapitalisme aan te pakken? De historisch-ontologische conclusie van Marx, dat met de opkomst van de moderne bourgeoisie de klassenstrijd als principe van de geschiedenis kenbaar wordt, wordt hier ogenschijnlijk oppervlakkig gesteld, maar niet in zijn volledigheid doordacht.

Vervolgens komen we aan bij de hoofdmoot van het werk. Dit derde hoofdstuk borduurt voort op het principiële idee van Theorie van de kraal, namelijk dat in naam van de meritocratie een artificiële schaarste is gecreëerd die dienstdoet als ultieme drijfveer voor het zogenaamde 'rennen' - ofwel concurreren - in de kraal. Want, wat is de rol van de figuur van de hamster in dit alles? In de woorden van Schinkel: "Hamsteren leidt wellicht tot tekorten aan bepaalde waren op sommige plaatsen en op sommige momenten, maar met de creatie van schaarste, zou ik hier duidelijk willen maken, heeft het niets te maken. Het hamsteren kan veroordeeld worden omdat het levens-middelen schaars makkt, maar in wezen wijst het hamsteren ons op het dieperliggende feit dat 'schaarste' altijd een sociaal geproduceerd gegeven is" (ibid., 119). Overigens geen origineel punt, Hans Achterhuis betoogde in 1988 nog iets soortgelijks met zijn Het Rijk van de Schaarste. Maar de hamsteraar toont ons nogmaals aan dat schaarste niet het uitgangspunt van de economie is, maar juist een effect. Het gevolg van de specifieke indeling van de economie zoals die in het logistiek kapitalisme is vormgegeven. Kritiek die ook al door Horkheimer en Adorno is geformuleerd: kapitalisme is burgerlijke berekendheid, reductie tot abstracte kwantiteiten.

In hoofdstuk vier wordt hier verder op ingegaan, onder de noemers just-in-time-kapitalisme, of ook wel logistiek kapitalisme. Het probleem van onze 
huidige economische situatie is namelijk niet slechts het kapitalisme in de zin van financialisering van meerwaarde en het kenmerkende gegoochel van geldcirculatie door banken, investeringsmaatschappijen, etc. maar ook en vooral de logistiek die achter de geglobaliseerde toevoerlijnen schuilt. Deze analyse is tegelijk een kracht en een zwakte in het betoog van Schinkel. Het is namelijk performatief, middels zijn benaming van logistiek kapitalisme probeert Schinkel zowel onze situatie te duiden als een construct in het leven te roepen dat een bepaalde coherentie moet verlenen aan wat anderzijds wellicht losse aspecten zijn. Zo schakelt het betoog tussen verschillend ietwat fragmentarische kritiek als de klassieke marxistische op automatisering, waarbij een problematische vorm van vervreemding optreedt, tot een meer immanente kritiek dat just-in-time logistiek eigenlijk niet echt just-in-time is, dat het niet echt efficiënt is omdat het slechts de voorraden die nog kenmerkend waren voor het Fordistisch kapitalisme naar 'achteren' duwt, onzichtbaar makt voor de consument. Hier wordt de verbinding met het hamsteren gemaakt, omdat nu juist aan de zichtbare kant van de 'supply chain' bij de 'handelaren' (zoals Schinkel ze dubbelzinnig duidt) het beeld wordt opgeworpen van een schaarste die eigenlijk geen schaarste is. Een schaarste die altijd al artificieel was en in dienst is van de circulatie van geld, goederen, mensen, et cetera. Deze analyse en het daarmee innig verweven pleidooi kan niet afgedaan worden als een simpele terugkeer naar fordistische voorraden. Hoewel Schinkel enigszins verwijtend wijst naar het gebrek aan voorraden in de zorg tijdens de corona-pandemie makkt het vooral pijnlijk duidelijk hoe diep het logistiek kapitalisme ons bestaan heeft gepenetreerd (ibid., 119).

\section{Politiek spel of theoretische gevolgtrekking?}

Schinkels poging is wat zijn doeleinde betreft noemenswaardig. Niet alleen is de hamsteraar als figuur, zoals Schinkel het zegt, een vervreemdend affect, een moment waarin wij ons niet helemaal één voelen met de just-in-time-organisatie van onze maatschappij, maar ook is deze figuur op zich niet veel kwalijk te nemen. Zonder de hamsteraar te bagatelliseren werpt Schinkel zich op tegen de burgerlijke reflex de hamsteraar voor 'idioot' uit te maken, of erger: parasiet. Niet de hamsteraar, die uit gevoelde noodzaak een eigen voorraad aanlegt is parasitair, nee, de architecten van het systeem, de eigenaren van de globale ketens, middels hun artificiële schaarste en zogenaamd noodzakelijke ordening, zijn de echte parasieten. Schinkels betoog moet dan ook zo gelezen worden, als een verschuiving van de aandacht naar deze vaak in het narratief van de hamsteraar buiten schot gebleven figuren. Hoewel dit werkt in een positionele strijd om aandacht, is het theoretisch lastiger vol te houden. Acceptatie van het begrip schaarste leidt volgens Schinkel tot een acceptatie van het historisch gegroeide systeem zoals deze is. Tegelijkertijd is dit ogenschijnlijk in strijd met het idee dat niet alleen bepaalde natuurlijke bronnen eindig zijn, maar ook dat het menselijke begrensd is. 'Begrensd' in zijn onvolledigheid, zoals ook in de Theorie van de kraal wordt benadrukt. Dit ontkent namelijk niet het probleem van de menselijke en natuurlijke eindigheid, wat zou neerkomen op een klassiek modernistisch betoog, maar situeert het probleem juist op zo'n manier dat het niet onterecht ten koste gaat van een deel van de mens of van het leven in het algemeen. Net zoals schaarste geen beginpositie, maar resultante is, zo ook overvloed. 
Voor Schinkel is dan ook niet de vrije markt het probleem, die heeft namelijk nooit bestaan. Nee, de 'macht' is het probleem. Zoals Schinkel zelf zegt: "achter alles wat 'markt' heet, staat de macht, en uiteindelijk het geweld" (ibid., 225). Het zijn dus niet de globale markten die invloed uitoefenen op overheden of andere pogingen tot democratisch zelfbestuur, die daar dus niet in de ban van zijn geraakt, maar andersom. Andermaal volgt Schinkel hier Adorno en Horkheimer, de vrije markt en de burgermaatschappij in zijn algemeen zijn slechts werktuigen van staten, wiens rol tegelijkertijd beperkt is tot borg staan voor de metriek: zoals er in de $19^{\text {de }}$ eeuw nog ergens in een Franse kluis een platina staaf lag die de meter garandeerde. Hoewel Schinkel daarmee terecht wijst op de ideologische dimensie van het kapitalisme, dat het geen natuurlijk fenomeen is, verdwijnt een belangrijk inzicht. Namelijk, het idee dat bestuursvormen via instituties van de staat, behorende tot de parlementaire democratie, pogingen zijn tot collectief zelfbestuur, maar tegelijkertijd, op het moment dat het strijdveld daar gelokaliseerd wordt, onder constante spanningen staan precies vanuit de 'instrumentele wereld' in habermasiaanse zin. Spanningen die inherent zijn aan de democratie als poging antagonistische krachten op enigerlei wijze te situeren en mediëren, zodat zelfbestuur überhaupt mogelijk wordt. Hoogmoed echter, vanuit Schinkels perspectief, want dat vereist ogenschijnlijk het soort scheiden en berekenen dat intervenieert in het leven. Operaties die alleen aan het leven zelf, gelezen door een omkering van een spinozistische formule, ofwel alleen aan God zijn besteed. Natura sive Deus.

Om het probleem in de termen van Theorie van de kraal te bespreken, fascisme, kapitalisme en neoliberalisme, zijn precies het soort 'vrije woekeringen' dat Schinkel theoretisch gezien interessant vindt. De consequentie ervan echter is dat wanneer wij vrije woekeringen op zijn beloop laten gaan, deze bijna altijd parasiterend of verstikkend werken op andere woekeringen. Snel vermenigvuldigende woekeringen (zoals onkruid, of voor dierlijke organismen: kanker) nemen de ruimte, zuurstof en energie van de woekeringen eromheen in. Een pleidooi voor vrije woekering is daarmee niet voldoende, een pleidooi voor een gelijke, eerlijke, of gemeenschappelijke woekering is meer op zijn plaats. Maar, hoe zo'n woekeringsvorm te realiseren als niet via een bepaalde vorm van democratische politiek die op het niveau van een orde werkt? Schinkel zelf neemt ook zo'n (super)positie in, met als nieuw ordeningsprincipe: woekeringen mogen niet ten koste gaan van andere woekeringen.

Deze impasse wordt duidelijk in het laatste hoofdstuk van De hamsteraar, waarin Schinkel van leer trekt tegen het RIVM en het OMT specifiek. Hij verwijt hen zich in te laten met calculaties over leven, elke ingecalculeerde dode is er één te veel. Daarmee toont Schinkel zich andermaal protestants-kantiaans: het leven is te kostbaar om mee te rekenen. Toch wordt dit betoog problematisch als Schinkel besluiten over het open houden dan wel ondersteunen van specifieke sectoren of instituties bekritiseert. Kritiek op de te grote invloed van het economisch belang is terecht, de nationale luchtvaartmaatschappij kreeg bovenmatig veel steun, maar om vervolgens in naam van specifiek leven - aan te duiden als naakt leven in de termen van Agamben - te betogen dat er geen enkele dode mocht worden ingecalculeerd laat vervolgens andere aspecten van dat leven, van de kwaliteit van het leven, buiten beschouwing. Schinkel noemt daarbij de mogelijke heropening van de scholen, bij uitstek een politiek besluit, waar het RIVM 
en het OMT specifiek overwegingen probeerden te maken hoe de kwaliteit van leven van een grote groep jongeren niet permanent schade aan te richten, een onvermijdelijk antagonistische overweging tussen verschillende levens - niet tussen leven en kapitaal.

Schinkel eindigt zijn Hamsteraar dan ook met een eigenaardige wende, een bijna paternalistisch lijstje van richtpunten, een "tienpuntenlijstje dat we op toiletpapier zouden kunnen schrijven, zoals op het keerpunt in de film V for Vendetta" (ibid., 244). Wat volgt zijn tien 'al bekende punten' die ter herinnering worden ingebracht en tegelijk erg lijken op de zogenaamde nostalgie voor de sociale welvaartstaat die Schinkel een paar bladzijden daarvoor nog afdoet. Op zich allen overtuigend, zoals bijvoorbeeld: democratisering van productiemiddelen en communicatiemiddelen, garantie van inkomen, groene energievoorziening, planning in plaats van prijsmechanismes in de economie, etc. (welke hij overigens herhaalt in het laatste hoofdstuk van Pandemocratie). Maar de bescheidenheid en abstractie van het lijstje, gekoppeld aan de nadruk op herhaling, doen vermoeden dat het zware mediërende werk van de democratie, waarin erkenning en overtuigingskracht tussen radicaal verschillende perspectieven centraal staat, slechts vooruit wordt geschoven.

\section{Naar de pandemocratie}

Uiteindelijk is Schinkel met recht niet alleen socioloog, maar ook echt een filosoof te noemen. Precies omwille van wat hij zelf nu juist zo problematisch vindt: het kunnen scheiden. Dat betekent niet alleen het onderscheid maken op hoog theoretisch niveau, het op begrip kunnen brengen van de hedendaagse conditie van de mens. Maar, ook juist als affectieve operatie, als vervreemding. Schinkel probeert ons te vervreemden van de alledaagsheid van het onrecht veroorzaakt door de systemen die wij hebben opgetogen om zelf om te gaan met die moderne conditie. We mogen daarin juist niet al te erg met deze systemen samenvallen, maar moeten altijd een beetje vervreemd zijn en daarmee vragen kunnen stellen bij wat vanzelfsprekend lijkt.

Maar, Schinkel lukt het niet om daar consistent in te zijn, waarop hij overigens meteen zal antwoorden dat consistentie op zich helemaal geen doel is of kan zijn. Sterker nog, het devies is eerder: wees hypocriet, spreek je uit tegen de praktijken waar je zelf deel van uit maakt. Maar het soort inconsistentie hier is anders. Het theoretisch model dat is opgetuigd staat ergens haaks op de meer ecologische, socialistische en antiracistische leest waarop de inhoudelijke lijnen van zijn recente werk is geschoeid. De vervreemding is namelijk niet alleen de preconditie van kritiek, maar op zich de menselijke conditie, dat wat eigen is aan mensen, dat ze nooit echt samenvallen met de zelf-opgetogen systemen of de natuur. Anders gezegd, orde is te ontmaskeren als woekering, maar menselijke woekeringen zijn per definitie niet slechts woekeringen, kennen ook altijd een dimensie van 'orde' — de menselijke reflectie, overweging, calculatie, is altijd ingebed in zo'n woekering. Ook Schinkels programma is uiteindelijk een woekering die zichzelf als orde op zal stellen, een orde die weliswaar meer ruimte laat aan de pluriformiteit van leven, maar als het niet zelf weer slechts verstikkende blinde wildgroei is - om met de woorden van Slavoj Žižek te schermen, die een uitspraak van Lynn Margulis op zijn kop zette: Moeder natuur is een wrede moeder - een orde niettemin. Schinkel heeft daarin veel weg van een rousseauiaans romanticus, terug naar 
de 'amour de soi' voordat deze gecorrumpeerd werd door de maatschappij, specifiek het kapitalisme. En zelfs optimistischer over 'consensus' dan Habermas, want waar consensus bij Habermas een mogelijkheid is die nog verwerkelijkt moet worden via het zware werk in instituties en de pogingen een ander te begrijpen, is dat voor Schinkel klaarblijkelijk iets dat vooral verschijnt als we er niet aan werken, als we niet proberen te begrijpen, maar als we leven maar leven laten zijn en woekeringen laten woekeren. Daarmee slaat Schinkels theoretische betoog de onderbouwing voor zijn praktische programma compleet weg.

Tegelijk zal Schinkel zeggen dat zijn programma dit ook juist ingecalculeerd heeft, dat het einde ervan niet door hem, maar door de democratie zal moeten worden geschreven. Maar, hoe verhouden we ons dan tot de uitkomsten van het democratisch proces als die ook weer onrecht gedeeltelijk verankeren als recht? Omdat Schinkel voornamelijk in wat Hegel de negatieve vrijheid van het denken noemt blijft hangen, is de tweede stap van elk denken, de 'positivering', ofwel dat elke begrenzing tegelijk eigenlijk mogelijkheidsvoorwaarde is, bij Schinkel een oppervlakkige constatering. Nergens wordt dit zo duidelijk als in zijn analyse van de natiestaat. Of de duiding hoe de Europese Unie dit reproduceert. In een interview met Lex Bohlmeijer voor De Correspondent vertrekt Schinkel voornamelijk vanuit het idee dat solidariteit wordt begrensd, letterlijk, door de natiestaat en tegenwoordig door de Europese Unie. ${ }^{2}$ Met alle gevolgen, alle verloren levens aan de Griekse kust van mensen die mee willen delen in het veilige en welvarend leven dat Europa voor zijn burgers heeft opgetogen, van dien. Kritiek op de huidige staatsvorm is meer dan terecht ook gegeven zijn historische opkomst, die innig is verweven met de opkomst van nationalisme en kapitalisme, twee van Schinkels belangrijkste theoretische doelwitten.

En passant noemt Schinkel echter een belangrijk aspect van die staat, namelijk dat het zelf juist een poging of mogelijkheidsvoorwaarde tot solidariteit was. Waaraan ik zou toevoegen: omdat er daarvoor nog veel minder solidariteit was, omdat solidariteit geen natuurlijk gegeven is, maar geconstrueerd moet worden. Met de tot nu toe meest grootschalige poging tot zo'n solidariteit, de natiestaat en in het verlengde de Europese Unie, ontstonden ook de grootste praktijken van uitsluiting en de vooropplaatsing van het eigen belang van het politiek subject als resultante van solidariteit. Anders gezegd, ruimte voor de kritische boodschap van Schinkel is er zeker en terecht wijst Schinkel ons op de mogelijkheid en de noodzaak van een grotere solidariteit, in lijn met de internationale, in de geest van de oproep van Marx en Engels aan het eind van het communistisch manifest, en zoals Schinkel ook in De hamsteraar oproept: een vereniging aller hamsteraars (ibid., 255). Een constructie blijft het echter wel.

Vandaar ook de titel van zijn meest recent werk op het moment van schrijven, Pandemocratie. Hierin neemt Schinkel eenzelfde houding aan tegenover de complotdenker als tegenover de hamsteraar. Andermaal hebben ze gelijk dat er iets niet pluis is aan de bestaande orde, maar hun antwoorden zijn fascistisch. Pandemocratie is niet slechts een analyse van de democratie in pandemische tijden, waarin het biologistieke rekenen omklapt in een necropolitiek, een politiek gekenmerkt door dood (laten gaan), maar ook een oproep tot een democratie voor allen, een democratie die niet alleen de buitengesloten mensen, maar al het leven includeert (2021,17-18). Zoals Schinkel zegt: 
"de democratisering van alles (pan) en voor iedereen (demos)" (ibid., 256). Dit mondt uit in een drievoudige 'uitbreiding' langs de domeinen die wij al terugzien in Theorie van de kraal: 1. Naar rechtelozen en onderdrukten, 2. Naar collectieve vormen van economische democratie, 3. Naar wat tot nu toe slechts bekend stond als 'natuur' (ibid., 257). Een rizomatische weergave van inzichten van figuren als Bruno Latour, Donna Haraway, en Cedric Robinson. Maar, meer dan een opsomming van die inzichten wordt het ook weer niet. Juist omdat dat programma van inzichten niet logischerwijs volgt uit het theoretisch raamwerk dat Schinkel al sinds Sociale hypochondrie op probeert te zetten.

Schinkel is een verrijking voor het Nederlandse publieke debat. Zijn moedige pogingen om ondanks bedreigingen - Schinkel werd genoemd door Vizier op Links, een van de Nederlandse alt-rightgroepen - perspectieven toe te voegen aan het debat in naam van rechtvaardigheid rondom precies de drie hiervoor benoemde domeinen politiek, economie en ecologie, is prijzenswaardig. Maar, de weg daarnaartoe is niet overtuigend en kent een onvoorzien effect. In zijn theoretische zoektocht naar de ultieme bevrijding onder het juk van de liberale orde vandaan en zijn programmatische activisme die gedeeltelijk gestoeld is op precies dezelfde ideologische operaties, blijft er weinig over van democratie. Want wat voor soort democratie is er nog bij Schinkel als ons zelfbestuur eigenlijk alleen aan God zelf toevertrouwd is? Als elke poging orde aan te brengen in Gods natuurlijke woekeringen per definitie fascistisch is? Een onmenselijke democratie.

\section{Literatuurlijst}

Schinkel, Willem. 2010. Aspects of Violence: A Critical Theory. London: Palgrave Macmillan.

Schinkel, Willem en Rogier van Reekum. 2019. Theorie van de kraal: kapitaal-ras-fascisme. Amsterdam: Boom uitgevers.

Schinkel, Willem. 2020. De hamsteraar: kritiek van het logistiek kapitalisme. Amsterdam: Boom uitgevers.

Schinkel, Willem. 2021. Pandemocratie. Editie Leesmagazijn.

\section{Notes}

1 Zie bijvoorbeeld: https://bij1.org/speechwillem-schinkel/

2 Zie voor het interview: https://www.felix-ensofie.nl/boeken/536/willem-schinkel--denken-ineen-tijd-van-sociale-hypochondrie/

3 Zie voor het gesprek met Lex Bohlmeijer: https://decorrespondent.nl/12188/welkom-in-deeeuw-van-de-necropolitiek-waar-bedrijven-enstaat-over-lijken-gaan/859165661376-5b62f7fb

\section{Biography}

Jamie van der Klaauw is promovendus 'politieke theorie en zijn geschiedenis' aan de Erasmus School of Philosophy. Zijn proefschrift gaat over (politieke) representatie als mediatie, waarin hij probeert het concept tot zijn radicale eindpunt te doordenken. Daarnaast houdt hij zich bezig met sociale en culturele filosofie. In 2021 verscheen van zijn hand het artikel: "Conspiracy Theories as Superstition: Today's Mirror Image in Spinoza's Tractatus Theologico-Politicus." 